\title{
THE ROLE OF DISTRIBUTIVE JUSTICE, PROCEDURAL JUSTICE, BUDGETARY GOAL COMMITMENT AND JOB RELEVANT INFORMATION IN MEDIATING EFFECT OF BUDGETARY PARTICIPATION ON MANAGERIAL PERFORMANCE
}

\author{
Novitasari Iga*, Suardhika I Made Sadha, Sari Maria M. Ratna, Wirajaya I Gde Ary \\ Post-graduate Program, Udayana University, Bali, Indonesia \\ *E-mail: iganovitasari88@gmail.com
}

\begin{abstract}
Accountability and performance transparency is an important aspect for public sector organizations as an embodiment of the obligations of public or governmental organizations in accounting for the success / failure of program implementation. The Government is obliged to make accountability report in the form of Performance Report of Government Institution. The inconsistency of the study results prompted the authors to reexamine the effect of budgetary participation on managerial performance with distributive justice, procedural fairness, commitment to budget objectives and job-related information as a mediating variable. In implementing all of its obligations to manage funds from the community in a transparent and accountable manner, the government prepares an activity budget. The level of achievement of program activities in the Work and Budgeting Planning (RKA) is strongly influenced by budgetary participation.
\end{abstract}

\section{KEY WORDS}

Budgeting participation, managerial performance, distributive justice, procedural justice, budgetary goal commitment, job relevant information.

Not only are central government obligations, local governments are also required to not only be able to realize vertical accountability, i.e reporting to superiors, but also capable of realizing horizontal accountability, i.e reporting to Regional House of Representatives (DPRD) and communities (Mardiasmo, 2005). The Government is obliged to prepare an accountability report in the form of Government Instance Performance Report (LKjIP) in accordance with the mandate of Presidential Regulation number 29 of 2014 on Performance Accountability System of Government Institution and its compilation which refers to Ministry of Administrative and Bereaucratic Reform (Permenpan-RB) Regulation number 53 of 2014 on the Technical Guidelines of Performance Agreement, Performance Reporting and Procedure of Review of Performance Report of Government Agencies. The preparation of LKJIP is expected to be an implementation and government commitment in creating good governance and clean government and transparent and accountable in order to realize result oriented government.

In an effort to support the implementation of performance measurement, the government has made Government Accountability System Performance Accountability (SAKIP). SAKIP is a government performance measurement system, which is used to determine the ability of government in achieving the vision, mission and goals of the organization. Performance measurement is needed to measure the level of achievement of the various programs that have been set, measure the achievement of the results and benefits that should be obtained in order to realize good governance. In implementing all of its obligations to manage funds from the community in a transparent and accountable manner, the government prepares an activity budget. The budget is the main instrument used by the government in implementing the established policies.

Performance benchmarks are a measure of the success achieved for each defined program. In a performance-based budget system the performance benchmark used is work performance. As an organization that implements performance-based budgets, local governments must have clear performance benchmarks. Each program as outlined in the 
Work and Budget Planning (RKA), and how the level of achievement of the program will be a reference of the performance of the OPD.

Several previous studies that have examined the effect of budgetary participation on managerial performance have found mixed and inconsistent results. Researched by Ulupui (2004), Adrianto (2008), Arifin (2012), and Amertadewi (2013) found that there was a positive and significant influence between budgetary participation on managerial performance. While research conducted by (Lilik Subagyo, 2004) shows that there is no significant relationship between the participation of budgeting on managerial performance. Meanwhile, the results of Milani K. (1975), Chenhall and Brownell (1988) and Medhayanti and Suardana (2015) studies showed that there is a negative relationship between budget participation in managerial performance. Sumarno (2005) shows that budget participation has a negative and significant effect on managerial performance. While research conducted by Supomo, B., and Nur (1998), Ismiriati (2013), and Sinuraya (2009) indicate that there is no influence between the participation of budget preparation on managerial performance. The inconsistency of the research results is due to the contingency factor in the relationship of budgetary participation and managerial performance (Anthony and Govindarajan, 2005). Contingency variables can be either moderating or intervening variables (Nor, 2007).

This research is a development of research conducted by Giri (2014). In the study, researchers examined the effect of budgetary participation on managerial performance with procedural fairness, distributive justice and budgetary commitment commitments as mediating variables. The analytical technique used is Partial Least Square (PLS) with the location of research conducted at General Hospital Center (RSUP) Sanglah Denpasar. Meanwhile, this study examines the effect of budgetary participation on managerial performance with distributive justice, procedural fairness, commitment to budget objectives and job-related information as a mediating variable performed in the Regional Government Organization (OPD) of Badung Regency Government. The difference of this study with previous research is, this research adds one mediator variable that is job relevant information (JRI) with research location is at public sector organization that is OPD Badung Regency Government. OPD Badung Regency Government was chosen as the object of research because, Badung Regency is one of the regencies with the highest District Own Source Revenue (PAD) in Bali.

\section{LITERATURE REVIEW}

Equity Theory. This theory explains that, someone motivation is related to equity, and fairness and justice applied by the management. According to Adam (1965) and Greenberg (1986) equity is focused on the relative ratio of outcomes that employees derive from their input, compared to standards as a basis for judging justice for a relationship. This theory assumes that when we engage in interpersonal relationships, we will always evaluate those relationships by comparing our own input-output ratio with others, so that we can determine under reward, over eward (equally valued), equitably reward should be). The input in question is any contribution given by the individual in carrying out his work or relationship. Input can be time, energy, work loyalty, commitment, trust in leadership, tolerance, ability, flexibility, and others. While output (outcome) is a positive and negative consequences that individuals feel the effects of input given. Outcomes can include compensation, recognition, promotion, reputation, responsibility, and more. Justice can be used as a way to resolve conflicts, select employees, resolve conflicts among employees, and negotiate salaries (Greenberg, 1986).

Goal Setting Theory. The goal-setting theory is a theory of cognitive motivation based on the premise that a person has needs that can be thought of as specific outcomes or as a target (Locke and Bryan, 1968). The goal setting theory describes the relationship between a defined goal and work performance. The goal-setting theory dictates that goals are specific (specific) and difficult, with feedback will lead to higher performance (Robbins and Judge, 2008: 237). A person's commitment to a particular goal will also affect the actions of its performance consequences. So it can be said that, the goal is a form of motivation that sets 
the standard for someone self satisfaction on performance (Hudayati, 2002). The basic concept of goal setting theory is that employees who understand the goals (what the organization expects them to be) will have an effect on their work behavior (Locke, 1986). Difficult goals will result in higher achievement compared to easy goals, while clear and challenging goals will result in higher achievement compared with abstract goals (Arfan, 2010: 90). There are five main principles of goal setting theory consisting of clarity, challenge, commitment, feedback and task complexity (Locke and Latham, 1986).

Contingency Approach. Contingency variables are needed because in the research the relationship of budgetary participation to the performance of the researchers tends to focus on the general question of whether budget participation is effective or not to performance, without focusing on what conditions the budget participation can be effective. Indriantoro and Supomo (2001) explained that the mediating factor is the type of variables that influence the relationship between independent variables and dependent variable into indirect relationship. The mediating variable is a variable located between the independent variable and the dependent variable, so the independent variable does not directly affect the dependent variable. Ghozali (2012) explains that the mediating factor is a factor or variable that is influenced by a variable and influences other variables. Contingency factors used as the mediating variables in this study are distributive justice, procedural fairness, commitment to budget goals and Job Relevant Information. The variable acts as a mediating variable that is considered capable of being a mediator in the causal relationship of the effect of budgetary participation on managerial performance.

Budgetary Participation. Budgetary participation is defined as the process by which individuals whose performance is evaluated for award based on the achievement of budget targets, are engaged and have influence in budget targets (Brownell, 1982). Participation in the preparation of the budget is the participation of top managers to subordinates in the process of determining the resources to be used in an activity and their own operations (Eker, 2007). With participation in budgeting, managers will be involved in considering and evaluating budgetary alternative alternatives (Kren, 1992). The participation in the budgeting process will encourage increased communication between superiors and subordinates. With the participation in the preparation of the budget is expected to create alignment goals between the individuals involved in the process of budgeting with the goals of the organization as a whole.

Distributive Justice. Distributive justice is defined as a reasonably accepted evaluation is relative to the work done (Greenberg, 1986). Meanwhile, Folger and Konovsky (1989) define distributive justice as perceived fairness in terms of the amount of compensation employees receive. Distributive justice is an employee's assessment of the fairness of outcomes received by an employee of an organization (Greenberg, 1990, Niehoff and Moorman, 1993 in Alotaibi, 2001). Magner and Johnson (1995) state distributive justice in terms of outcomes because the emphasis is on the distribution received, regardless of how the distribution is determined. Distributive justice is essentially achievable if the outcome / acceptance and input between two persons / two employees is comparable. If the proportion of the proportion received is comparable or greater, then it is possible to say that it is fair, and this has an impact on their work. However, if the proportion of the proportion received is smaller than the other, then there is the possibility that it is said to be unfair and that this will affect their work (Supardi, 2008). Individual justice perceptions will increase as the individual's involvement increases in the budgeting process (Wentzel, 2002). Distributive justice in question is not limited to the association, but also includes distribution, distribution, placement and exchange (Fatturochman, 2002).

Procedural Justice. Procedural justice is organizational justice that deals with decisionmaking procedures by organizations addressed to its members (Alotaibi, 2001). Procedural justice is justice that takes into account mechanisms that support employee empowerment and provide support to employees. Procedural justice refers to the justice rules and procedures by which awards are distributed (Alexander and Ruderman, 1987 in Supardi, 2008). Magner et al., In Beugre (1998) argues that managers or managers should avoid using arbitrary and arbitrary procedures in allocating existing resources. In order for the 
organization to do so, the manager / manager must develop rules or procedures related to his work clearly and in which there is a communication mechanism from the bottom up (propose). If this is done, then most likely this will impact on the work that has been done. Based on several definitions of procedural justice it can be concluded that procedural justice is related to the perceived justice in the process of making a decision. Maria and Nahartyo (2012) also stated that procedural justice will cause a person to accept a decision, even if it does not agree with the outcome of the decision, because the decision-making process is done fairly. Furthermore, Maria and Nahartyo (2012) assert that fair process becomes the accepted norm for behavior, both in social context and in the context of organizational decision making process.

Budgetary Goal Commitment. Maiga and Jacobs (2007a) altered the budgetary goal commitment as determination and persistence to try to achieve money goals from time to time. Someone will perform better when he is committed to achieving a certain goal. To achieve budgetary goal commitment can occur when subordinates have accepted the established goals, and can be done because there are funds (Indarto, 2011). Budgetary goal commitment becomes important because productivity (mostly) of whether the organization achieves its financial goals (Wentzel, 2002). Magner et al. (1996) in Maiga and Jacobs (2007a) also states that subordinates are highly their budgetary goal commitment seeking interaction with people who have knowledge, performance, task strategies, and other issues, who have been hiding in performance. The budgetary goal commitment is something that is essential to achieving budget goals and perseverance in taking action from those funds (Locke et al., 1981). Commitment demonstrates a strong belief and Usefulness of the value and purpose (goal) to be achieved (Mowdey et al, 1979). Thus, as many as have a high budgetary goal commitment will be positive and try their best to achieve the purpose of money.

Job Relevant Information. In an organization there are two main types of information: (1) manager behavior information in decision making for job evaluation, (2) information for decision making in order to achieve better results (Kren, 1992). Job relevant information (JRI) is defined as information that can facilitate decision-making relevant to the task (Kren, 1992: 511). JRI aims to facilitate decision-making related to the task. JRI is needed by top managers to take strategic steps in achieving the goals that have been set. According to Murray (1990) information can be transferred from subordinates to his superiors. It shows that there are two advantages gained from the transfer of information: (1) the superior can develop a better strategy, which can be submitted to the subordinate so that performance can increase, (2) from information obtained from subordinates; decision level taken by the boss will be better or more suitable for the organization. When a subordinate or budget executive is given an opportunity to provide input in the form of information it has to the boss or user budget then the boss will gain a better understanding of the relevant information to the task (Krisler et al., 2006). Based on these definitions can be concluded that job relevant information is information related to tasks that can assist managers in the decision-making process. The exchange of information that occurs is expected to provide better knowledge to both parties regarding alternative decisions and appropriate actions to achieve the goal.

Managerial Performance. Managerial performance is one factor that can be used to improve the effectiveness of an organization (Sumadiyah and Susanta, 2004). Performance in an organization is a form of response to the success or failure of the goal of an organization. Government performance within the scope of macro organizational review includes the goals, ideals and expectations of an organization that is endeavored by its achievements by all elements of the organization. Government performance is determined by the vision and mission of the organization, where to achieve the vision and mission is needed motive. Without the drive or motive to achieve the vision and mission, then the performance will not work. Performance can be run with the support of facilities, infrastructure, competence, opportunities, standards, and feedback.

Hypothesis:

$\mathrm{H}_{1}$ : Budgetary participation to managerial performance; 
$\mathrm{H}_{2}$ : Role of distributive justice on budgetary participation arrangement to managerial performance;

$\mathrm{H}_{3}$ : Role of procedural justice on budgetary participation arrangement to managerial performance;

$\mathrm{H}_{4}$ : Role of budgetary goal commitment on budgetary participation arrangement to managerial performance;

$\mathrm{H}_{5}$ : Role of job relevant information on budgetary participation arrangement to managerial performance.

Based on literature review of theory and hypothesis, the conceptual framework in this study is:

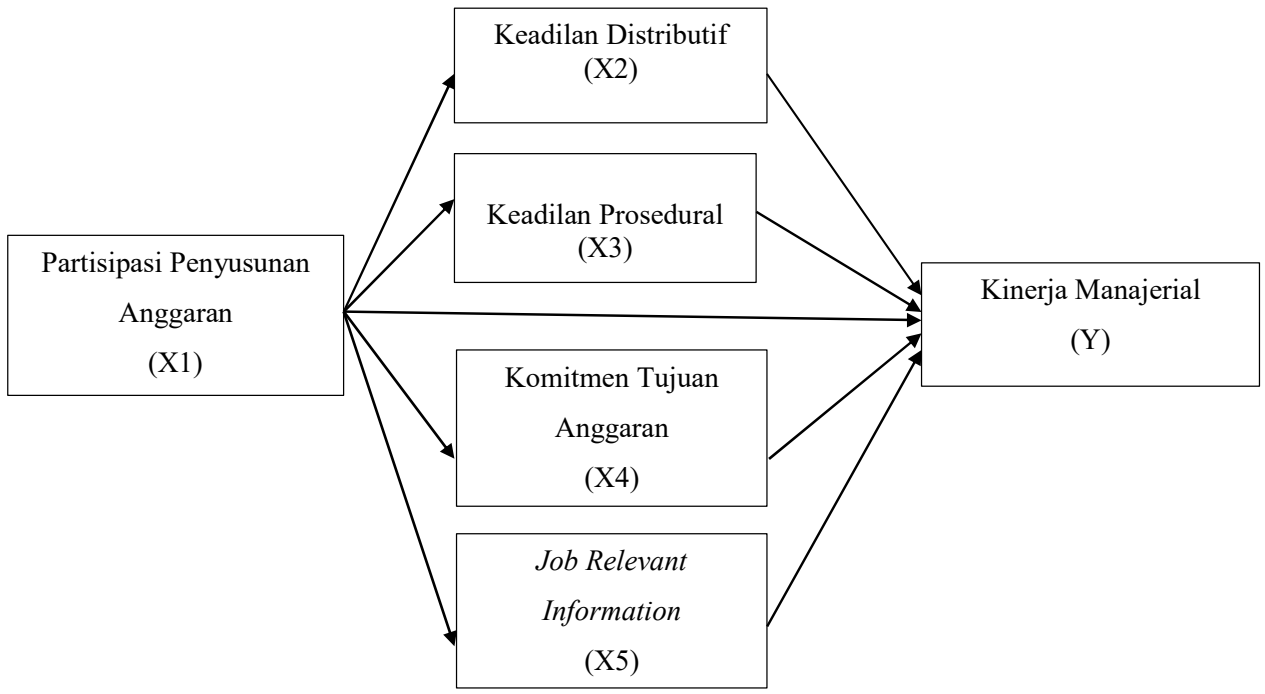

Figure 1 - Conceptual Framework

\section{METHODS OF RESEARCH}

This study uses a research instrument in the form of a questionnaire to collect primary data. The questionnaire is a collection of data that is done by giving a set of written statement to the respondent to be answered. Questionnaires were given to the Commitment Making Official (CMO) and the Technical Executing Officer (TEO) at the Badung District Government OPD in the 2017 Budget Year, which is used as the research sample or the respondent of this research. Data analysis in this research using Partial Least Square (PLS) approach using SmartPLS solfware. PLS is a powerful method of analysis and is often referred to as soft modeling because it eliminates the Ordinary Least Square (OLS) assumptions such as, the data must be normally distributed and the samples not necessarily large.

\section{RESULTS AND DISCUSSION}

The respondents in this study were represented in all productive age categories, but the level of respondents' dissemination was uneven. In this study the majority of respondents aged $46-50$ ie as many as 137 people or $31.0 \%$ and age above 50 years is also as many as 137 people or $30.7 \%$. In that age range, respondents are considered to have good emotional stability (stable), so have a good acceptance of a procedure applied. In addition to that age range, respondents are assumed to have better communication and decision-making skills in relation to the budgeting process. Respondents in this study majority have more than 9 years working period of 350 people or $79.2 \%$. While respondents with a working period of 3-6 years is the least that is as much as 2 people or by $0.5 \%$. Viewed from the respondent profile based on the working period it can be assumed that most of the respondents in this study have had good experience and understanding in the scope of work and responsibility on the process of budgeting participation, so it is expected to provide more objective answers. 
respondents with the last education at bachelor degree is as many as 286 people or $64.7 \%$, while respondents with the last education at master degree is as many as 156 people or $35.3 \%$. Based on the above data respondents in this study have the level of undergraduate Education i.e bachelor degree and master degree, based on it is expected respondents can provide better answers, thorough and objective to the actual situation of the question in the distributed questionnaire. Respondents with a period of involvement in the process of budgeting with time less than 3 years ( $<3$ years) is 34 people or $7.7 \%$, respondents with involvement of budget preparation with a period of 3-5 years is as many as 48 people or $10.9 \%$, while the respondents with the involvement of the preparation of the budget 6-8 years is as many as 148 people or $33.5 \%$. Last respondents with a period of involvement in the preparation of the budget more than years ( $>9$ years) is as many as 212 people or by $48.0 \%$. Based on the above data the majority of respondents in this study have involvement in the preparation of the budget is more than 9 years, then with the period of involvement in the budget process respondent assumed to have sufficient experience in the process of budget preparation so that respondents are expected to provide better answers, clear, thorough and objective to the actual state of the question in the distributed questionnaire.

$R$ square value serves to see the significance of latent variables. The model is considered to have an effect when R2 is more than 0 (zero). $R$ square value of each variable in this study can be seen in Table 1 as follows:

Table 1 - Determination Coefficient

\begin{tabular}{lll}
\hline & R Square & R Square Adjusted \\
\hline Distributive Justice (X2) & 0,290 & 0.288 \\
Procedural Justice (X3) & 0,227 & 0.225 \\
Budgetary Goal Commitment (X4) & 0,063 & 0.061 \\
Job Relevant Information (X5) & 0,316 & 0.315 \\
Managerial Performance (Y1) & 0,482 & 0.476 \\
\hline
\end{tabular}

Source: Primary Data, 2018.

Based on Table 1 the coefficient of determination R2 is 0.482 . It indicates that managerial performance variability (Y1) which can be explained by the participation of budgeting $(X)$, distributive justice $(X 2)$, procedural justice $(X 3)$, commitment of budget goals (X4) and job relevant information (X5) is $48.2 \%$, while the remaining $51.8 \%$ is explained by another variable not examined in the model. Distributive justice is explained by budget participation of $29.00 \%$, the rest explained by other factors outside the model of $71.00 \%$. Procedural fairness is explained by the participation of the drafting of the remaining $22.7 \%$ is explained by other factors outside the model of $77.3 \%$. The commitment of budget objectives is explained by the participation of the $6.3 \%$ drafting of the remaining $93.7 \%$ explained by other factors outside the model. Job relevant information is explained by the participation of $31.6 \%$ drafting the rest is explained by other factors outside the model of $68.4 \%$.

Q-square predictive relevance for the structural model is used to measure how well the observation values are generated by the model and also the parameter estimates. A model is said to have a relevant predictive value if the $Q$ square value is more than $0(>0)$. Predictive relevance values are derived from:

$$
\begin{aligned}
& \mathrm{Q}^{2}=1-\left(1-\mathrm{R}_{1}{ }^{2}\right)\left(1-\mathrm{R}_{\mathrm{n}}{ }^{2}\right) \\
& \mathrm{Q}^{2}=1-\left(1-\mathrm{R}_{1}{ }^{2}\right)\left(1-\mathrm{R}_{2}{ }^{2}\right)\left(1-\mathrm{R}_{3}{ }^{2}\right)\left(1-\mathrm{R}_{4}{ }^{2}\right)\left(1-\mathrm{R}_{5}{ }^{2}\right) \\
& \mathrm{Q}^{2}=1-\left(1-0,290^{2}\right)\left(1-0,227^{2}\right)\left(1-0,063^{2}\right)\left(1-0,316^{2}\right)\left(1-0,42^{2}\right) \\
& \mathrm{Q}^{2}=1-(1-0,084)(1-0,051)(1-0,004)(1-0,100)(1-0,232) \\
& \mathrm{Q}^{2}=1-(0,916)(0,949)(0,996)(0,900)(0,768) \\
& \mathrm{Q}^{2}=0,402
\end{aligned}
$$

Based on the calculation of $Q$ square, it is obtained that the model has good predictive relevance (Q2> 0). $Q$ square predictive relevance value of $40.2 \%$ indicates that the data diversity can explain the model of $40.2 \%$ or in other words information in the data of $40.2 \%$ 
can be explained by the model, while the remaining $59.8 \%$ is explained by other variables (variables that have not been contained in this model and error)

Exogenous variables are significant on endogenous variables if the t-statistic is greater than t-table $1,965(2.5 \%$ significance level, DF $=436)$. The result of direct influence test of each variable can be seen in table 2 as follows:

Table 2 - Direct Effect

\begin{tabular}{lccc}
\hline & T Statistics $(\mid \mathrm{O} /$ STDEV $\mid)$ & t-Table & Description \\
\hline X1 -> X2 & 14,389 & 1,965 & Significant \\
X1 - X3 & 12,523 & 1,965 & Significant \\
X1 - X4 & 6,149 & 1,965 & Significant \\
X1 - X5 & 17,809 & 1,965 & Significant \\
X1 -> Y & 3,783 & 1,965 & Significant \\
X2 - Y & 4,072 & 1,965 & Significant \\
X3 - Y & 11,206 & 1,965 & Significant \\
X4 -> Y & 0,416 & 1,965 & Not significant \\
X5 - Y & 1,765 & 1,965 & Not significant \\
\hline
\end{tabular}

Source: Primary Data, 2018.

Table 2 shows that the t-statistic value of budgetary participation on distributive justice is 14,441 more than the value of $t$-table 1,965 . This means that budgetary participation has a significant effect on distributive justice. The t-statistic value of budgetary participation on procedural justice 13.096 is more than the value of t-table 1,965. This means that budgetary participation has a significant effect on procedural justice. The t-statistic value of budgetary participation to budgetary goal commitment is 6.161 more than the value of t-table 1,965 . This means that budgetary participation has a significant effect on budgetary goal commitment. The t-statistic value of budgetary participation on job relevant information is 12,776 more than the value of t-table 1,965. This means that budgetary participation has a significant effect on job relevant information. The value of t-statistic budgetary participation (X1) on managerial performance (Y1) is 3.584 more than t-table 1,965. The result means that budgetary participation has a significant effect on the managerial performance. The t-statistic value of distributive equity in managerial performance is 3.977 more than the value of $t$-table 1,965. This result explains that distributive justice has a significant effect on managerial performance. The t-statistic value of procedural justice in managerial performance is 10.848 more than the value of t-table 1,965. This result explains that procedural justice has a significant effect on managerial performance. The value of t-statistic budgetary goal commitment on managerial performance of 0,516 is less than the value of t-table 1,965. These results explain that the budgetary goal commitment has no significant effect on managerial performance. The value of t-statistic job relevant information on managerial performance of 1,180 is less than the value of t-table 1,965. This result explains that job relevant information has no significant effect on managerial performance.

The results of indirect effect of latent variables analyzed through SmartPLS version 3.2.6 can be seen in Table 3.

Table 3 - Indirect Effect

\begin{tabular}{cccccc}
\hline & Original Sample (O) & Sample Mean (M) & Standard Deviation (STDEV) & T Statistics (|O/STDEV $\mid)$ & P Values \\
\hline$(\mathrm{X} 1)->(\mathrm{Y} 1)$ & 0,292 & 0,293 & 0,038 & 7,710 & 0,000 \\
\hline
\end{tabular}

Source: Primary Data, 2018.

The value of indirect effect $X 1$ is 0.292 obtained through the number of multiplication coefficient of budget participation path $(\mathrm{X} 1)$ on managerial performance (Y1) through distributive equity moderation moderation $(X 2)$, procedural fairness $(X 3)$, budget goal commitment (X4) and job relevant information (X5) that is: $(0,538 \times 0,223+0,476 \times 0,468+$ $0,252 \times-0,017+0,562 \times-0,084)$ so that obtained by result of indirect effect value equal to 0,292 . 


\section{CONCLUSION}

Budgetary participation arrangement has an effect on managerial performance. This means that the higher the involvement of the Commitment Making Official (CMO) and the Technical Executing Officer (TEO) in the budgeting process, will be able to improve managerial performance.

Budgetary participation effect on managerial performance with distributive justice as the mediating variable. This means that with increased budgetary participation involving the Commitment Making Official (CMO) and Technical Executing Officers (TEO), will lead to an increase in the perception of distributive justice, which in turn will result in improved managerial performance.

Budgetary participation effect on managerial performance with procedural justice as a mediating variable. This means that an increased budgetary participation involving the Commitment Making Official (CMO) and the Technical Executing Officer (TEO) will result in increased perceptions of procedural justice, which will ultimately lead to improved managerial performance.

Budgetary participation does not effect on managerial performance with budgetary goal commitment as a mediating variable. This means that an increase in budgetary participation Commitment Making Official (CMO) and Technical Executing Officer (TEO) will result in increased budgetary goal commitment but increased budgetary goal commitment does not improve managerial performance.

Budgetary participation does not effect on managerial performance with job relevant information as a mediating variable. This means that an increase in budgetary participation involving the Commitment Making Official (CMO) and Technical Executing Officer (TEO) will result in increased job relevant information, but the increase in job relevant information is not able to improve managerial performance.

Research Limitation. This study has some limitation. Firstly, the use of self-rating scale on the measurement of managerial performance can lead to linear bias, where respondents have a tendency to answer their performance is too high. Further research can measure performance without using self-rating scale, but the assessment is done by colleagues or leaders.

Secondly, this research was conducted at the Regional Device Organization (OPD) up to the Sub-District level, in line with the regulation change on the WTO which based on the Government Regulation Number 18 of 2016 which is meant by the Regional Device Organization (OPD) of all elements of regional apparatus namely the Regional Secretariat, Expert Staff, Secretariat of the House of Representatives (Sekretariat DPRD), Inspectorate, Regional Office, Agency, Technical Implementation Unit, District and Sub-District. Subsequent research can examine all the regional devices in question, including the Expert Staff Technical Implementation.

Thirdly, The development of subsequent research on the relationship between budgetary participation and managerial performance can use other mediating variables such as budgetary adequacy, clarity of budget objectives and internal controls. The adequacy of the budget gained from participation in the budgeting process will improve managerial performance because the availability of sufficient budget will be able to represent the needs of each area of accountability so that performance will increase (Indarto and Ayu, 2011).

\section{REFERENCES}

1. Adam G. Alotaibi, 2001, Antecedents of Organizational Citizenship Behavior: A Study of Public Personnel in Kuwait, Public Personal management, 30, 3, 363-376.

2. Adrianto, Y., 2008, Analisis Pengaruh Partisipasi Penyusunan Anggaran Terhadap Kinerja Manajerial Dengan Kepuasan Kerja, Job Relevant Information Dan Kepuasan Kerja Sebagai Variabel Moderating, 
3. Amertadewi, 2013, Pengaruh Partisipasi Anggaran Terhadap Kinerja Manajerial Dengan Gaya Kepemimpinan dan Locus of Control Sebagai Variabel Moderasi, E-Jurnal Akuntansi Universitas Udayana, 3, 550-566.

4. Anthony dan Govindarajan, 2005, Management Control System, edisi ke 11, F.X Kurniawan, ed., Salemba Empat, Jakarta.

5. Arifin, S., 2012, Pengaruh Partisipasi Penyusunan Anggaran Terhadap Kinerja Aparat Pemerintah Daerah: Komitmen Organisasi, Budaya Organisasi, Dan Gaya Kepemimpinan Sebagai Variabel Moderasi, Skripsi Undip, 1-24.

6. Brownell P., 1982, The Role of ACcounting in Performance,

7. Chenhall dan Brownell, 1988, The Effect of Participative Budgeting on Job Satisfaction and Performance Role Ambiguity as an Intervening Variable, Accounting and Organization Society, 13, 225-233.

8. Eker, M., 2009, The impact of budget participation on managerial performance via organizational commitment: A study on the top 500 firms in Turkey, Ankara Üniversitesi SBF Dergisi, 64, 4, 117-136.

9. Giri, M., 2014, Pengaruh Partisipasi Penganggaran Pada Kinerja Manajerial Dengan Keadilan Distributif, Keadilan Prosedural, Dan Komitmen Tujuan Anggaran Sebagai Variabel Pemediasi,

10. Greenberg, 1986, Determinants of Perceived Fairness of Performance Evaluations, Journal of Applied Psychology, 71, 340-342.

11. Greenberg, 1990, Organizational Justice: Yesterday, Today, and Tomorrow, Journal of Management, Volume: 16, 2, 399-432.

12. Hudayati, A., 2002, Perkembangan Penelitian Akuntansi Keperilakuan: Berbagai Teori Dan Pendekatan Yang Melandasi, Jaai, 6, 2, 81-96.

13. Indarto, S.L. \& Ayu, S.D., 2011, Pengaruh Partisipasi Dalam Penyusunan Anggaran Terhadap Kinerja Manajerial Perusahaan Melalui Kecukupan Anggaran, Komitmen Organisasi, Komitmen Tujuan Anggaran, Dan Job Relevant Information (Jri), Seri Kajian IImiah, 14, 1, 32-44.

14. Ismiriati, 2013, Analisis Implementasi Sistem Pengendalian Intern Pemerintah, AKuntabilitas dan Transparansi Terhadap Kinerja Pemerintah,. Universitas Bengkulu,

15. Konovsky, O. dan, 1989, Cognitive Versus Affective Determinants of Organizational Citizenship Behavior, Journal of Applied Psychology, 74, 157-164.

16. Kren, L., 1992, Budgetary Participation and Managerial Performance: The Impact of Information and Environmental Volatility, The Accounting Review, 67, 3, 511-526.

17. Locke, E.A., et al., 1981, Goal Setting and Task Performance: 1969-1980,

18. Locke, Edwin A, Karyll N.Shaw, Lise M.Saari, G.P.L., 1980, Goal Setting and Task Performance: 1969-1981, Technical Report.

19. Magner, N. dan G.G.J., 1995, Municipal Official's Reactions to Justice in Budgetary Resource,, PAQ Winter, 436-439.

20. Maiga, A.S. dan Jacobs, F.A., 2007, Budget Participation's Influence on Budget Slack: The Role of Fairness Perceptions, Trust, and Goal Commitment, Journal of Management Accounting Research, 5, 1, 3-58.

21. Mardiasmo, 2005, Akuntansi Sektor Publik, andi, ed., Yogyakarta.

22. Maria dan Nahartyo, E., 2012, Influence Of Fairness Perception And Trust On Budgetary Slack: Study Experiment On Participatory Budgeting Context,, 1-63.

23. Medhayanti, N.P. \& Suardana, K.A., 2015, Pengaruh Partisipasi Anggaran Terhadap Kinerja Manajerial dengan Self Efficacy, Desentralisasi, dan Budaya Organisasi Sebagai Variabel Pemoderasi, E-Jurnal Akuntansi Universitas Udayana, 1, 155-170.

24. Milani K., 1975, The Relationship of Participation in Budget-Setting, to Industrial Supervisor Performance and Ettitudes: A Field Study, The Acc. Rev., 50 (2), 247-284.

25. Murray, D., 1990, The Performance Effects of Participative Budgeting, An Intergration of Intervening on Moderating Variables, Behavioral Research in Accounting, 2, 104-123.

26. Nor, W., 2007, Desentralisasi dan gaya kepemimpinan sebagai variabel moderating dalam hubungan antara partisipasi penyusunan anggaran dan kinerja manajerial, Simposium Nasional Akuntansi X, 1-27. 